УДК 342.9

\author{
О.О. Маркова \\ orcid.org/0000-0001-9970-0944 \\ кандидат юридичних наук, доцент, \\ доцент кафедри юридичних дисииплін \\ Сумської філії \\ Харківського національного університету внутрішніх справ
}

\title{
ДОЗВІЛЬНА ПРОЦЕДУРА В УКРАЇНІ
}

Діяльність органів виконавчої влади, місцевого самоврядування набуває адміністративно-правової форми за допомогою адміністративної процедури, яка є однією з головних форм реалізації виконавчої влади. Різноманіття адміністративної діяльності органів публічного управління потребує використання різних видів адміністративних процедур. Значне місце в діяльності органів виконавчої влади посідає дозвільна система, яка становить досить значну частину в загальному обсязі управлінської діяльності, її можна порівняти 3 такими видами діяльності, як нормотворча та контрольно-наглядова. Вона посідає важливе місце у сфері державного управління ще й тому, що досить широким є коло її об'єктів (ï режим), для яких необхідний регламентований порядок надання дозволів. Нині вже склалася значна сукупність не тільки матеріальних, а й процедурних адміністративно-правових норм, які регулюють відносини між суб'єктами дозвільної системи (дозвільними органами та заявниками). Матеріальні норми містяться в законодавстві про статус, компетенції суб'єктів дозвільної системи. Йдеться про положення та інші акти, які наділяють суб'єктів дозвільної системи повноваженнями надавати дозволи у процесі регулювання відповідних видів діяльності. До матеріальних норм дозвільної системи зараховують також правові норми, що надають заявникові право отримати дозволи на певний вид діяльності або об'єкт дозвільної системи [1, с. 5]. Процедурні норми містяться і закріплюються в законах, які регламентують безпосередньо порядок: подання заяви на отримання дозволів на певний вид діяльності або об’єкт, її розгляд уповноваженим органом виконавчої влади й ухвалення відповідного акта у формі видання дозволу чи відмови у виданні або застосування санкцій за невиконання умов і вимог, зазначених у дозвільних документах, а також порядок переоформлення, анулювання дозволів.

Якість нормативно-правового регулювання дозвільної системи визначається наявністю трьох елементів: 1) належної нормативної підстави для здійснення дозвільної діяльності; 2) нормативно-правового регулювання порядку реалізації та виконання дозвільних повноважень; 3) загально- го Закону «Про адміністративну процедуру». Адміністративна процедура підвищує для заявників і одержувачів дозволів зрозумілість і прозорість здійснення дозвільних повноважень, оскільки містить вичерпний перелік представлених документів і підстав для відмови в наданні позитивного результату. Наразі законодавча регламентація дозвільної діяльності на законодавчому рівні здійснюється, як правило, шляхом включення «дозвільного компонента» в правову тканину законів, які регулюють різногалузеві відносини. 3 огляду на різноманітність форм дозвільної діяльності і специфічний правовий режим об'єктів, стосовно яких провадиться така діяльність, укажемо на наявність широкого спектра таких законодавчих актів, як Закон України «Про дозвільну систему у сфері господарської діяльності", Закон України «Про ліцензування окремих видів діяльності», закони України «Про ветеринарну медицину», «Про основні засади та вимоги до безпеки і якості харчових продуктів», «Про ринок електричної енергії», «Про реєстрацію фізичних осіб-підприємців та юридичних осіб і громадських формувань»; Закон України «Про оцінку майна, майнових прав і професійну оцінну діяльність в Україні» та ін. Другий елемент визначає якість нормативного регулювання цієї діяльності. Зазначимо, що відсутність детального нормативно-правового регулювання переліку та порядку виконання дозвільних повноважень органами виконавчої влади, а також невизначеність, дублювання повноважень, недостатня процедурна регламентація дозвільної діяльності є причинами довільного обмеження прав громадян і юридичних осіб, а також підвищення корупційного ризику ії здійснення і нестабільності системи державного управління. Зважаючи на таку ситуацію, вчені пропонують систематизувати основні положення про дозвільну систему шляхом розроблення спільного закону для цієї сфери (спільної законодавчої регламентації дозвільної системи незалежно від сфери) - «Про дозвільну систему». Цей закон допоможе вирішити більшість поставлених завдань: уніфікувати дозвільну термінологію через нормативне закріплення понять, об'єктів, форм і методів дозвільної діяльності; визначити склад і 
основні повноваження дозвільних органів, включаючи правові заходи впливу, що застосовуються до суб'єктів, які порушують дозвільні вимоги. Важливим результатом подібного підходу стане об'єднання та уніфікація всього дозвільного законодавства в одному новому законі. Для української правової системи виправданим $€$ варіант ухвалення єдиного закону про дозвільну систему (на всі дозвільні дії державних органів мають бути безпосередні вказівки в законі). Це зумовлено необхідністю обмеження нерегламентованої дискреційної діяльності державних органів, зокрема й суб’єктів публічної адміністрації, з огляду на високий рівень корупції i, як наслідок, установлення надмірно високих адміністративних бар'єрів для вчинення регульованої діяльності.

Що стосується третього елемента, то вкажемо на його відсутність. Донині залишається ще не вирішеним одне із стратегічно важливих завдань, пов'язане з відсутністю функціонування уніфікованого процедурного механізму, - адміністративної процедури, що негативно позначається на якості вчинення адміністративної діяльності органів виконавчої влади, місцевого самоврядування в цілому і дозвільної діяльності зокрема. На сучасному етапі цілями здійснюваної адміністративної реформи в Україні є зниження адміністративних бар'єрів і підвищення якості та доступності державних і муніципальних послуг. Серед завдань, які необхідно вирішити для досягнення поставлених цілей, виділяється оптимізація механізмів здійснення функцій органів виконавчої влади i вдосконалення дозвільної діяльності в різних сферах суспільних відносин. Протягом останніх років відбувається не тільки розширення, а й ускладнення дозвільної системи, наповнення їі новими видами дозволів, уточнення дозвільних процедурних форм і адміністративних регламентів їх реалізації. Можна сказати, що деякою мірою підвищується рівень їі системності та раціональності. Загалом, розвиток дозвільної системи спрямований на поліпшення бізнес-клімату та усунення зайвих адміністративних бар'єрів, зокрема й щодо зниження тягаря, пов'язаного з ліцензуванням та іншими дозволами. Водночас дійсна дозвільна система залишається не тільки досить складною, суперечливою, а й значною мірою хаотичною. Сьогодні в Україні налічується понад 1200 різних видів дозволів, видання яких регламентується 167 законами, 150 постановами Кабінету міністрів, 1500 нормативними актами центральних і місцевих органів влади. Зрозуміло, що надалі в такому вигляді система існувати не може, оскільки вона є важливим адміністративним бар'єром для створення нових i розвитку вже наявних підприємств. Законодавство про дозвільну систему характеризується поширенням відсилочних і бланкетних норм, які регулюють порядок на- дання конкретних дозволів. Так, Закон України «Про правове становище іноземців» містить понад 20 відсилочних норм, які передбачають регулювання порядку надання дозволів у міграційній сфері вповноваженими органами виконавчої влади. У деяких випадках прийняті на підзаконному рівні нормативні правові акти, що регулюють дозвільну діяльність, містять розпливчасті формулювання, які сприяють надмірному розсуду. Наявність відсилочних норм у законі, бланкетність диспозицій, відсутність чіткості формулювання правових норм сприяють їх розширеному тлумаченню і одночасно створюють можливість для вчинення дій корупційного характеру [2, с. 17]. У європейському законодавстві існують різні моделі регулювання дозвільних відносин, що пов'язано 3 відмінностями правових систем, проте в багатьох країнах є закони, які регламентують дозвільну систему (Казахстан, Таджикистан, Молдова, Грузія). Міжгалузеві спільні закони про ліцензії та дозволи прийняті в Болгарії, Польщі. У США, наприклад, кожна конкретна адміністративна процедура (отримання ліцензії, оформлення візи, реєстрація права власності тощо) передбачає власний алгоритм, обсяг наданих і отриманих документів, проте всі вони передбачають дотримання обов'язкових вимог, установлених Законом США про адміністративну процедуру. Тобто положення Закону поширюються на всі адміністративні процедури незалежно від того, у якій сфері суспільних відносин вони реалізуються і який урядовий орган бере в них участь. Дотримання вимог норм, включених у цей правовий інститут, покликане обмежувати свавілля в реалізації дискреційних повноважень, зокрема й за допомогою введення легальних критеріїв дій учасників адміністративної процедури. А якщо взяти за постулат твердження про те, що тільки за допомогою впорядкування діяльності владних органів вона може мати такі характеристики, як відкритість і передбачуваність, то наявність у США Федерального закону про адміністративну процедуру, аналогічних законів штатів і міст, їх дотримання свідчить про послідовний рух до організації ефективного, прозорого та демократичного державно-адміністративного апарату, який у своїй повсякденній роботі орієнтується на інтереси приватних осіб. Положення Закону про адміністративну процедуру включає адміністративне нормотворення, ліцензування, квазісудову діяльність і судовий контроль [3]. Відповідно до Закону ліцензування - це процес діяльності адміністративного агентства, який стосується надання, продовження, відмови, скасування, призупинення, анулювання, відкликання, обмеження, доповнення, зміни або визначення умов дії ліцензії. В американському законі поняття «ліцензія» означає дозвіл, сертифікат, схвалення, реєстрацію, статутний документ, ін- 
корпорацію, виключення 3-під дії закону або інші форми санкціонування, які застосовуються адміністративним агентством. Крім адміністративних дозволів, існує система сертифікацій, що видаються неурядовими організаціями. На відміну від ліцензування сертифікація є добровільною i не може бути умовою вчинення діяльності. Сертифікацію здійснюють неурядові організації, які видають особі обмежене в часі визнання про відповідність професійним стандартам після виконання стандартизованих критеріїв. Як бачимо, американський законодавчий підхід у питанні дозвільної процедури сформований у межах загальної адміністративної процедури, позитивним аспектом якого є уніфікація дозвільної термінології, що вносить визначеність у праворозуміння. Для нашої правової системи оптимальним варіантом $\epsilon$ більш «звичний» механізм регулювання, який передбачає наявність спеціального регулювання, проте варто запозичити досвід європейських країн стосовно сформованого загального підходу до адміністративної процедури.

Розглядати адліністративну дозвільну проиедуру необхідно крізь призлу дозвільної систели, яка є їі основою. У Законі України «Про дозвільну систему у сфері господарської діяльності» законодавець дає визначення, однак із прив'язкою до господарської діяльності. А на підзаконному рівні в Положенні КМУ про дозвільну систему закріплюється загальне визначення - як особливого порядку виготовлення, придбання, зберігання, перевезення, обліку та використання спеціально визначених предметів, матеріалів і речовин, а також відкриття і функціонування окремих підприємств, майстерень і лабораторій із метою охорони інтересів держави та безпеки громадян [4]. Узагальнюючи авторські визначення різних учених-адміністративістів, А.Ф. Ноздрачов писав, що в доктринальному плані дозвільна система включає надання дозволів на вчинення дозволеної діяльності (дій) або на охоронювані об’єкти дозвільної системи; нагляд за дотриманням умов і правил дозвільної системи; вжиття заходів адміністративного впливу стосовно порушників правил дозвільної системи [5].

Таким чином, загальновизнаною є позиція, згідно з якою дозвільна система включає два види діяльності. Основою системи є діяльність із надання різноманітних дозволів. Вона доповнюється діяльністю з державного контролю (нагляду), спрямованого виключно на перевірку дотримання умов надання дозволу. Нагляд і дозвіл - два тісно пов'язані елементи комплексного державного регулювання, вони повинні застосовуватися скоординовано. Незважаючи на уявну відмінність у правових наслідках, нагляд і дозвіл схожі з точки зору адміністративно-управлінських процесів, адже в обох випадках проводиться оцінювання від- повідності об'єкта контролю обов'язковим вимогам; оцінка здійснюється за допомогою перевірки особи або об'єкта. Фактично наглядова і дозвільна діяльність провадяться одними і тими самими органами щодо один і тих самих підприємців.

Поняття "дозвільна система» за своїм змістом є комплексним, оскільки включає цілий спектр дій органу, спрямованих на прийняття правонадільного адміністративного акта про надання дозволу, контроль за дотриманням правил дозвільної діяльності, переоформлення, призупинення, анулювання дозволу.

Особливість адміністративної дозвільної процедури зумовлена специфікою дозвільної системи. Стисло охарактеризуємо її основні риси:

1) відносна заборона, встановлена обмежувальними нормами, закріплена безпосередньо або опосередковано (коли вчинення певної діяльності або виконання дій заборонене без отримання відповідного дозволу) [6];

2) цілеспрямований характер; безперервність і циклічність; кореляція суб'єкта і об'єкта; правовий простір, у якому провадиться дозвільна діяльність (особливості, притаманні їй як елементу державного управління) [6];

3) націленість дозвільної системи на забезпечення безпеки особистості, суспільства та держави. За допомогою дозвільної діяльності з певного кола суспільних відносин виключаються суб'єкти і предмети (знаряддя виробництва, речовини тощо), які не відповідають установленим вимогам безпеки;

4) результат дозвільних правовідносин у вигляді прийняття індивідуального акта-дозволу на вчинення діяльності (вчинення дії), яка є юридичним фактом, що породжує, змінює або припиняє правовідносини різної правової природи (адміністративні, цивільні, трудові тощо) [7];

5) виникнення адміністративно-правового режиму (який можна зарахувати до легалізувальних режимів) у результаті дії дозвільної системи. Такий режим характеризує спеціальний адміністративно-правовий статус здобувача дозволу i суб'єкта, який отримав дозвіл;

6) адміністративний нагляд за вчиненням дозволеної діяльності. Невід'ємною ознакою дозвільної системи є збереження адміністративно-наглядових відносин між владними і невладними суб'єктами протягом усього строку дії дозволу;

7) застосування заходів адміністративного примусу (зокрема й призупинення дії або анулювання дозволу) у разі порушення правил дозвільної системи.

Процедурна сторона дозвільної діяльності реалізується шляхом здійснення дозвільного провадження. Згідно з наявною думкою дозвільне провадження становить окремий вид провадження, в межах якого встановлюється порядок здійснення конкретних дозвільних процедур (надання дозво- 
лу, проведення попередніх контрольних заходів, застосування оперативних санкцій до невладного суб'єкта дозвільних правовідносин тощо) [8]. Мета цієї процедури, як і контрольно-наглядової, різнопланова: забезпечити державну та громадську безпеку, захистити громадян, суспільство, державу від шкоди, яка їм може бути завдана неправомірним вчиненням суб'єктами дозволеної законом діяльності, щодо якої встановлено відносну заборону; запобігти неприпустилил ризикал, пов'язанил із заподіянням шкоди життю, навколишньому середовищу, з обмеженням конкуренції, з нерівномірним доступом до обмежених ресурсів, із порушенням безпеки особистості, суспільства та держави.

Призначення процедури - встановити порядок здійснення органами виконавчої влади дозвільних повноважень і гарантувати заявникам можливість реалізувати своє право на отримання конкретного виду дозволу на об'єкт або діяльність за умови дотримання ними всіх вимог, установлених законом. При цьому можливість отримання юридичною або фізичною особою такого дозволу ставиться в залежність від наявності різних умов і розсуду адміністративних органів, які здійснюють видання дозволів. Значення дозвільної системи зумовлюється характером об'єктів, щодо яких вона застосовується. Ці об'єкти становлять потенційну небезпеку людям, їх життю та здоров’ю, а також навколишньому середовищу.

Як зазначає I. Кириченко, до об'єктів правовідносин, що виникають у сфері дозвільної системи, можна зарахувати тільки конкретні предмети, речовини (як сукупність предметів з особливим режимом функціонування), які саме через свої екстраординарні властивості і включаються в систему зазначених правовідносин [9]. Аналізуючи мету і значення процедури, можемо виділити функції цієї процедури, які формуються залежно від функціональної спрямованості органу. Однією з основних функцій процедури є визначення та закріплення правил видання дозволів фізичним i юридичним особам, а також установлення вимог щодо режиму об’єкта або діяльності в аспекті її вчинення [10]. Серед додаткових функцій можемо виділити: 1) попереджувальну; 2) контролю; 3) правореалізації 4) забезпечувальну. Як функція забезпечення безпеки дозвільна діяльність потребує проведення як мінімальних перевірок пропонованих заявником документів у процесі реєстрації юридичної особи або індивідуального підприємця, так і тривалих заходів під час ліцензування окремих видів діяльності [11].

Адміністративна дозвільна процедура встановлює межі для вчинення дозвільної діяльності. Ці два поняття взаємопов'язані, оскільки без діяльності процедура не зможе функціонувати, а без процедури діяльність буде хаотичною, довільною та невпорядкованою. Що стосується змістового наповнення цих понять, то необхідно зазначити, що нормативне визначення дозвільної діяльності органів влади та перелік її видів в українському законодавстві відсутні, однак поняття «дозвільна процедура" закріплене в Законі України «Про дозвільну систему у сфері господарювання» . Під дозвільною процедурою законодавець розуміє сукупність дій, здійснюваних адміністраторами та дозвільними органами під час проведення погодження (розгляду), оформлення, надання висновків тощо, які передують отриманню документа дозвільного характеру [12]. Існують різні пропозиції вчених щодо визначення поняття «дозвільна процедура», однак найбільш повним і точним можна вважати таке: ие порядок вчинення (спеціальним ) суб'єктол публічної адліністрацї̈ ділльності, спрялованої на видання фізичнил $і$ юридичнил особал дозволів на вчинення певних видів діяльності, а також здіиснення інших юридично значущих дій щодо об'єктів (дозвільної систели) із подальшил контролел і наглядом за дотриланнял правил і улов вчинення дозволеної діяльності.

Зміст адміністративної дозвільної процедури полягає в: 1) наданні дозволу провадити діяльність або вчиняти дії щодо об'єкта фізичним i юридичним особам через ініціювання процедури; 2) установленні заборон провадити діяльність або вчиняти окремі дії без проходження фізичними та юридичними особами в уповноважених органах обов'язкових адміністративних процедур, зокрема й щодо різних об'єктів і предметів, стосовно яких передбачається провадити діяльність або вчиняти дії; 3) установленні за запитами фізичних та юридичних осіб уповноваженими органами індивідуальних приписів про вчинення діяльності або вчинення дій у певний спосіб, тільки за дотримання яких діяльність або дії будуть законними.

Види дозвільної процедури залежать від форм дозвільної діяльності. Н.В. Субанова пише про наявність дев'яти найбільш поширених форм цієї діяльності (як мінімум): ліцензування; надання дозволу; сертифікації; атестації; акредитації; квотування; реєстрації; надання інших видів дозволів (включення до реєстру, надання права, посвідчення, паспорт тощо) [13].

Учасниками дозвільної процедури може бути досить широке коло суб'єктів (органи виконавчої влади різних рівнів, інші наділені публічно-владними повноваженнями органи, організації та посадові особи, юридичні та фізичні особи, експерти), що поділяються на владних і невладних [14, с. 147]. Ініціатором виникнення процедурно-дозвільних правовідносин є невладна сторона, тобто юридичні або фізичні особи, які звертаються за отриманням дозволу до вповноважених органів. Це означає, що особа самостійно вирішує питання про свій вступ у дозвільні правовідносини. Припи- 
нення правовідносин у цій сфері також може бути пов'язане з добровільним волевиявленням недержавного суб'єкта. Суб'єктами, які мають право звертатися за дозволом на вчинення відповідних видів діяльності, є юридичні та фізичні особи. Обмеження у колі осіб, які мають право бути заявниками на вчинення окремих видів діяльності або використання об'єктів дозвільної системи, встановлюються законодавством.

Суб'єкти адміністративної дозвільної процедури - це органи, організації та посадові особи, наділені публічно-владними повноваженнями 3 надання дозволів, контролю (нагляду) за дотриманням правил дозволеної діяльності. У Законі України «Про дозвільну систему у сфері господарської діяльності» закріплене поняття дозвільні органи, до яких належать суб'єкти, що надають адміністративні послуги, посадові особи, вповноважені видавати документи дозвільного характеру. Вони діють у межах наданої їм компетенції в установленому законодавством порядку та формах. Уповноваженими органами дозвільної процедури є органи виконавчої влади та органи місцевого самоврядування, які мають відповідну компетенцію і наділені публічно-владними повноваженнями з надання дозволів, нагляду за дотриманням правил дозвільної діяльності. Дозвільна компетенція вповноважених органів не передбачає широкої оперативної самостійності та наявності широких дискреційних повноважень. Законодавство, що стосується дозвільної сфери (діяльності), намагається врегулювати дозвільну компетенцію вповноважених органів із вичерпною повнотою [14]. Із цього випливає, що перелік юридичних фактів, на підставі яких можуть бути видані дозволи, досить чітко визначається в нормативно-правових актах; оформляються вони, як правило, в письмовій документарній формі. Дозволи мають спеціальні найменування, що відображають особливості цих індивідуальних адміністративних актів, які передбачаються окремими законами та іншими нормативно-правовими актами. Основою адміністративно-правового статусу суб'єктів дозвільної процедури є дозвільні повноваження. Система повноважень суб'єкта дозвільної діяльності (зміст компетенціі) включає конкретні правообов'язки, надані йому для здійснення покладених на нього завдань і функцій, які можна назвати дозвільними повноваженнями. Кожне дозвільне повноваження потребує наявності в статусі вповноваженого органу спеціальних правообов'язків. А щодо посадових осіб, які безпосередньо провадять дозвільну діяльність, можна говорити про їх спеціальний статус, елементами якого є не тільки правообов'язки та гарантії, а й зумовлені завданнями протидії корупції заборони, обмеження і вимоги до службової поведінки. У контексті дозвільної діяльності повноваження органів виконавчої влади згадуються як винятково 3 надання дозволів, так і щодо здійснення інших процедур дозвільного характеру (атестації, акредитації, сертифікації), вичерпний перелік яких нормативно не закріплений [15].

Під дозвільними повноваженнями пропонуємо розуміти передбачений законом правообов'язок спеціально вповноваженого органу публічної адміністрації, його посадових осіб учиняти дії, спрямовані на надання як дозволів (документів дозвільного характеру), так і дій контрольно-наглядового характеру, спрямованих на перевірку дотримання суб'єктами, які отримали дозволи, правил і умов під час учинення відповідної діяльності. У разі виявлення порушень із боку ліцензіата дозвільні органи можуть застосовувати адміністративні контрольно-наглядові заходи для запобігання порушенням правил, умов здійснення діяльності та притягнення винних до відповідальності.

Особливість дозвільних процедур полягає в тому, що для них не характерна жорстка послідовність стадій, як у юрисдикційних процедурах. На це звернув увагу Д.В. Шохін. Він констатуе, що саме відсутність належної уваги до адміністративно-процесуальних форм дозвільної системи породжує основні проблеми у взаєминах громадян і держави. $€$ чимало прикладів, коли дозвільні процедури не узгоджені з іншими управлінськими процедурами. Так, дозволи на викиди забруднювальних речовин в атмосферне повітря видаються в межах процедур, не погоджених із процедурами встановлення нормативів викидів. У межах реалізації зовнішньоуправлінської діяльності дозвільні процедури провадяться стадіально. Так, Д.Н. Бахрах виділяє такі види стадій дозвільного провадження: основні (попередня; збирання і аналіз інформації; прийняття рішення; його виконання; нагляд за додержанням особами, які отримали дозвіл, установлених вимог і умов); факультативні (атестація, акредитація дозволеної діяльності; переоформлення, продовження дозволів; застосування примусових заходів, припинення дії правонадільних актів). Водночас суттєві різночитання, що стосуються розуміння вченими і практиками стадій дозвільної процедури, їх кількості та змісту, поряд із відсутністю нормативного закріплення структури дозвільної процедури дають можливість, як видається, поставити питання про адекватність правового регулювання в розглядуваній сфері. У дозвільній процедурі можемо виділити такі стадії: 1) попередню (порушення дозвільної справи); 2) розгляду дозвільної справи і прийняття рішення; 3) виконання рішення; 4) контролю (нагляд) над дотриманням особами, які отримали дозвіл, установлених вимог і умов; 5) переоформлення, продовження дозволів; 6) застосування заходів примусу за допущені порушення правил і умов, припинення дії правонадільних актів Oc- 
танні три стадї̈ є факультативними. Дозвільна діяльність - різновид організувальної, регулятивної, творчої діяльності публічної адміністрації. У процесі організаційної діяльності не існує такої жорсткої послідовності стадій, як у юрисдикційних процесах: стадії організаційної роботи можуть здійснюватися паралельно, навіть мінятися місцями [16]. Так, відповідальність може настати раніше, ніж переоформлення ліцензії; нагляд і акредитація здійснюються в один і той самий час, при цьому атестацію можна вважати формою нагляду. Тому наведена послідовність стадій є умовною.

Початком дозвільної процедури є дії особи, яка бажає отримати документ дозвільного характеру, пов'язані з поданням заяви про видання дозволу. У невладного суб'єкта є право звернутися із заявою і, відповідно, порушити (ініціювати) дозвільну справу. Вимоги до змісту і форми заяви визначаються КМУ, а також законами: наприклад, у сфері ліцензування - органом ліцензування. Заявник зобов'язаний підготувати пакет документів дозвільного характеру. У багатьох випадках стягується плата за видання (переоформлення) документів дозвільного характеру (адміністративний збір), яка визначається відповідно до Закону України «Про адміністративні послуги» (п. 2 ст. 4). Прийняття від суб'єкта господарювання або вповноваженої ним особи заяви про отримання (переоформлення, анулювання) документа дозвільного характеру здійснюється адміністратором у центрі надання адміністративних послуг.

На цій стадії дозвільний орган провадить дії, спрямовані на перевірку заяви і пакета документів на предмет відповідності формальним вимогам. Якщо заявник не дотримується зазначених вимог, це може бути підставою для відмови у виданні документа дозвільного характеру. Однак відповідно до Закону «Про ліцензування окремих видів діяльності» «не допускається вимагати від претендента ліцензії подання документів, не передбачених $<\ldots>$ законами». Законом можуть установлюватися інші підстави для відмови у виданні документа дозвільного характеру. Відмова у виданні документа дозвільного характеру на підставах, не передбачених законом, не допускається. Реєстрація заяви означає, що заведено дозвільну справу, і породжує обов'язок суб'єкта влади його розглянути, а отже, крім усього іншого, перевірити дотримання обов'язкових загальних і спеціальних вимог. Спеціальні вимоги зумовлені специфікою окремих видів діяльності або режиму об'єкта. До них належать кваліфікаційні вимоги до претендентів ліцензії, працівників ліцензованої організації, наявність спеціальних приміщень, обладнання, технічних засобів. Якщо вимоги безпосередньо випливають із чинних норм і правил, то умови визначаються на основі правил, але з урахуванням конкретних обставин.
На другій стадії дозвільний орган розглядає дозвільну справу по суті, тобто збирає необхідну інформацію про об'єкт або діяльність і приймає рішення про видання дозволу або відмову, оприлюднюючи своє рішення на порталі електронних сервісів у порядку, визначеному Кабінетом Міністрів України. Аналіз нормативно-правових актів дає підстави розуміти поняття «дозвіл» як допуск, із яким пов'язується початок і вчинення дозволеної діяльності або використання дозволених об'єктів. Оформляється такий допуск за допомогою прийняття уповноваженим органом виконавчої влади - дозвільним органом за клопотанням фізичної або юридичної особи дозволу - індивідуального правозастосовного акта, що наділяє цю особу спеціальною правоздатністю або надає їй персональне суб'єктивне право (як-от дозвіл на введення об'єкта в експлуатацію). Із юридичної точки зору дозвіл має всі властивості адміністративного акта. Він $є$ індивідуальним правовим актом уповноваженого органу виконавчої влади про визнання або підтвердження державою виникнення, обмеження, переходу або припинення прав на об'єкти (предмети) дозвільної системи або на вчинення певної діяльності (дій).

Теоретично дозвіл можна назвати «подразумеваемым административным актом», відповідно до якого юридична або фізична особа отримує право на заняття відповідною діяльності за умови подання в установленому порядку заяви і документів у повному обсязі. Вид цього акта запозичено з положень Французького кодексу «Про взаємовідносини органів з громадянами», у якому закріплене положення про те, що "silence de l'administration vaut acceptation" - «мовчання адміністрації означає прийняття" (L. 231-1). Правовим наслідком отримання дозволу є новий статус здобувача дозволу, що включає юридичні обов'язки, які реалізуються в адміністративно-правових відносинах, підтверджувати відповідність установленим вимогам, підлягати контролю та нагляду.

Органи, які видали дозволи, під час здійснення нагляду мають право проводити планові та позапланові перевірки відповідності проваджуваної ліцензіатом діяльності ліцензійним вимогам і умовам, складати за результатами перевірки акти із зазначенням конкретних порушень і здійснювати інші повноваження відповідно до закону. Суб'єкт, який отримав дозвіл (установа, водій транспортного засобу та ін.), зобов'язаний забезпечити умови для проведення перевірок, зокрема й надати необхідну інформацію та документи. Фактично всі дозвільні органи одночасно є суб'єктами адміністративного нагляду. Отримання дозволу на вчинення певної діяльності не завжди повністю легалізує її результати, іноді потребує додаткової легітимації. У багатьох випадках продукція, що випускається, використовувані засоби, результа- 
ти роботи повинні бути сертифіковані відповідно до Закону України «Про технічні регламенти та оцінки відповідності». Для кожної стадії дозвільної процедури характерні певні етапи, які зумовлені специфікою діяльності, об’єкта, щодо яких видається документ дозвільного характеру.

Дозвільна система - одна 3 найскладніших у питанні формування уніфікованого регулювання, зважаючи на різноманіття сфер і форм дозвільної діяльності. Однак процедурний механізм відіграє ключову роль у впорядкуванні дій із боку суб’єктів дозвільної діяльності, створення легальних рамок для здійснення органами своїх повноважень щодо заявників, а також обмеження адміністративного розсуду. Сьогодні, як і раніше, не є достатньою процедурна регламентація дозвільної діяльності (незважаючи на суттєву активізацію ухвалення законів щодо здійснення дозвільних функцій органами виконавчої влади, деяку процедуалізацію порядку надання окремих видів дозволів). 3 огляду на відсутність єдиного законодавчого акта, що закріплює поняття, види адміністративної процедури, необхідним видається ухвалення закону «Про адміністративні процедури». Як показує зарубіжний досвід, найбільшу гарантію від адміністративних зловживань і порушень прав і свобод громадян можуть забезпечити тільки єдині правила (на противагу дійсній практиці галузевої законодавчої та відомчої регламентації адміністративно-розпорядчої діяльності суб’єктів публічної адміністрації).

Провівши аналіз Закону України «Про дозвільну систему у сфері господарської діяльності», вважаємо необхідним указати на його фрагментарність у питанні процедурної регламентації дозвільної системи в цілому: 1) відсутність систематизованого порядку проведення дозвільної процедури; 2) прогалину в питанні закріплення переліку та змісту дозвільних повноважень органів. Із положень закону зовсім не зрозуміло, які повноваження закріплені за дозвільним органом. Порівнюючи із законами «Про ліцензування господарської діяльності» $\mathrm{i}$ «Про державну реєстрацію юридичних осіб, фізичних осіб-підприємців та громадських формувань», зазначимо, що в цих нормативних актах досить детально регламентується питання, пов'язане 3 повноваженнями; 3) звернемо увагу на відсутність логіки в структуруванні положень закону: вони закріплені в досить хаотичному порядку, що не сприяє праворозумінню. Зазначене спричиняє правову невизначеність у здійсненні дозвільних повноважень органами виконавчої влади, місцевого самоврядування, створює передумови для порушення прав і законних інтересів невладних суб'єктів дозвільних правовідносин (фізичних і юридичних осіб). Необхідним є законодавче закріплення поняття дозвільної діяльності, її принципів, ознак, змісту та умов здійснення дозвільних повноважень органами виконавчої влади, уніфікація дозвільної термінології. Доцільною в цьому плані, на наш погляд, є розробка Закону «Про дозвільну систему» . Необхідно створити баланс між доктринальною та законодавчою концепціями розвитку дозвільної системи з метою формування понятійного апарату, визначення основ системного підходу до проектування сучасної моделі дозвільної системи як одного з найважливіших інструментів державного управління, систематизації принципів правового регулювання та організації контролю, розробки методологічних аспектів організаційно-правової бази дозвільної діяльності.

\section{Jimepamypa}

1. Осинцев Д.В. Разрешительная система в Российской Федерации : автореф. дис. ... канд. юрид. наук : 12.00.02, Уральский госуд. юрид. академия. Екатеринбург, 1995. С. 8

2. Правовые акты: антикоррупционный анализ : науч.-практ. пособие / И.С. Власов, А.А. Колесник, Т.О. Кошаева [и др.]; отв. ред. В.Н. Найденко, Ю.А. Тихомиров, Т.Я. Хабриева. Москва : Контракт, Волтерс Клувер, 2010.628 с.

3. Administrative Procedure Act. URL: https: //www.archives.gov/federal-register/laws/ administrative-procedure.

4. Положення про дозвільну систему від 29.10.2020. URL: https://zakon.rada.gov.ua.

5. Кнутов А.В., Плаксин С.М., Чаплинский А.В. Разрешительная деятельность в Российской Федерации; Нац. исслед. ун-т «Высшая школа экономики», Ин-т государственного и муниципального управления. Москва : Изд. дом Высшей школы экономики, 2017. $383 \mathrm{c}$.

6. Акопян О.А., Витушкин В.А., Карпова Н.И. Правовое обеспечение промышленности: Научно-практическое пособие. Москва : ИД «Юриспруденция», 2010. C. $180-181$.

7. Валяев Ю.К. Метод разрешения в административном праве России : монография. Москва : ЮНИТИ-ДАНА; Закон и право, 2009. С. 108.

8. Тихомиров Ю.А. Административное право и процесс : Полный курс. Москва, 2001. С. 325-327, $340-351$.

9. Кириченко И.Г. Административно-правовой порядок обеспечения разрешительной системы. Киев : Наук. думка, 1989. 208 с

10. Бахрах Д.Н., Российский Б.В., Старилов Ю.Н. Административное право: Учебник для вузов. 2-е изд., изм. и доп. Москва : Норма, 2005. 800 с

11. «Про ліцензування видів господарської діяльності»: Закон України від 02.03.2015. URL: https:// https://zakon.rada.gov.ua

12. Про дозвільну систему в сфері господарської діяльністю : Закон України 05.01.2006. URL: https://zakon.rada.gov.ua

13. Субанова Н.В. Разрешительные полномочия органов исполнительной власти в Российской Федерации. Москва : ИД «Юриспруденция», 2012.288 с.

14. Бахрах Д.Н. Разрешительная система в Российской Федерации. Актуальные проблелы и перспективы юридической науки и правоприменительной деятельности в Российской Федерации. Москва, 2008. T. 1. C. 147. 


\section{Анотація}

Маркова О. О. Дозвільна процедура в Україні. Стаття.

У статті автор проводить комплексне дослідження дозвільної процедури: іï правове регулювання, призначення, мету та функції, суб’єктів, структуру. Діяльнісна сторона дозвільної процедури реалізується крізь призму дозвільної системи, яка є комплексним поняттям і включає сукупність дій органу, спрямованих на прийняття правонадільного адміністративного акта про надання дозволу, контроль за дотриманням правил дозвільної діяльності, переоформлення, призупинення, анулювання дозволу. Особливість адміністративної дозвільної процедури зумовлена специфікою дозвільної системи, яка характеризується сукупністю ознак. Функціональна сторона дозвільної процедури реалізується шляхом здійснення дозвільного провадження як окремого виду провадження, в межах якого встановлюється порядок здійснення конкретних дозвільних процедур (надання дозволу, проведення попередніх контрольних заходів, застосування оперативних санкцій до невладного суб'єкта дозвільних правовідносин. Автор намагається пояснити та розкрити необхідність ухвалення єдиного загального Закону України «Про адміністративну процедуру», незважаючи на те, що існує Закон України «Про дозвільну систему у сфері господарської діяльності», який визначає правові та організаційні засади функціонування дозвільної системи у сфері господарської діяльності і встановлює порядок діяльності дозвільних органів, уповноважених видавати документи дозвільного характеру, та адміністраторів. В Україні повинен функціонувати уніфікований процедурний механізм, який буде відгравати ключову роль у впорядкуванні дій із боку суб'єктів дозвільної діяльності, створення легальних рамок для здійснення органами своїх повноважень щодо заявників, а також обмеження адміністративного розсуду. Як показує зарубіжний досвід, найбільшу гарантію від адміністративних зловживань і порушень прав і свобод громадян можуть забезпечити тільки єдині правила про адміністративну процедуру (на противагу дійсній практиці галузевої законодавчої регламента- ції адміністративно-розпорядчої діяльності суб'єктів публічної адміністрації).

Ключові слова: дозвільна процедура, дозвільна система, адміністративна процедура.

\section{Summary}

Markova O. O. Permitting procedure in Ukraine. Article.

In the article, the author conducts a comprehensive study of the licensing procedure: its legal regulation, purpose, goals and functions that it performs, subjects, structure. The operational side of the licensing procedure is implemented through the prism of the licensing system, which is a complex concept and includes a set of actions of the body aimed at adopting the authorizing administrative act on granting a permit, monitoring compliance with the rules of permitting activity, re-issuing, suspending, canceling a permit. The peculiarity of the administrative licensing procedure is due to the specifics of the licensing system, which is characterized by a set of features. The functional side of the permitting procedure is implemented through the implementation of the permitting procedure as a separate type of production, within the framework of which the procedure for the implementation of specific permitting procedures is established (granting a permit, conducting preliminary control measures, applying operational sanctions to the authorities of the subject of permitting legal relations. The author tries to explain and disclose the need to adopt a unified Act of Ukraine "On administrative procedure", despite the fact that there is the Act of Ukraine "On the licensing system in the field of economic activity", which defines the legal and organizational basis for the functioning of the licensing system in the field of economic activity and establishes the procedure for the activities of licensing authorities authorized to issue licensing documents, and administrators. As foreign experience shows, the greatest guarantee against administrative abuses and violations of the rights and freedoms of citizens can be provided only by uniform rules on the administrative procedure - in contrast to the existing practice of sectoral legislative regulation of administrative and administrative activities of public administration entities.

Key words: permitting procedure, permitting system, administrative procedure. 